\title{
The Kinetics of Manganese Sorption on Ukrainian Tuff and Basalt-Order and Diffusion Models Analysis
}

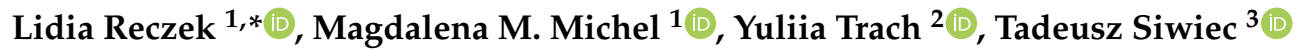 \\ and Marta Tytkowska-Owerko ${ }^{1}$ \\ 1 Institute of Environmental Engineering, Warsaw University of Life Sciences-SGGW, 02-787 Warsaw, Poland; \\ magdalena_michel@sggw.edu.pl (M.M.M.); marta_tytkowska@sggw.edu.pl (M.T.-O.) \\ 2 Department of Water Supply, Water Disposal and Drilling Engineering, National University of Water and \\ Environmental Engineering, 33028 Rivne, Ukraine; y.p.trach@nuwm.edu.ua \\ 3 Department of Environmental Engineering and Geodesy, University of Life Sciences in Lublin, \\ 20-069 Lublin, Poland; tadeusz.siwiec@up.lublin.pl \\ * Correspondence: lidia_reczek@sggw.edu.pl; Tel.: +482-2593-5162
}

Received: 11 October 2020; Accepted: 26 November 2020; Published: 28 November 2020

check for updates

\begin{abstract}
The study aimed to determine the nature of the kinetics of the manganese sorption process on Ukrainian tuff and basalt at different temperatures characteristic of the natural water environment. The scope of the research included manganese sorption kinetic test on natural mineral sorbents at temperatures of $10,17.5$ and $25^{\circ} \mathrm{C}$ in slightly acidic conditions. Sorption (pseudo-first order, pseudo-second order and Elovich models) and diffusion kinetic models (liquid film diffusion and intraparticle diffusion) were used in the analysis of test results. The manganese sorption process on both tuff and basalt proceeded quickly. The dynamic equilibrium state of manganese sorption settled after 35 and $45 \mathrm{~min}$ on tuff and basalt respectively. Although the process took place in a slightly acidic environment and below $\mathrm{pH}$ PZC of the sorbents, possible electrostatic repulsion did not inhibit the removal of Mn. The Mn sorption on both materials followed the PSO kinetics model. Based on the diffusion kinetic models, it was determined that Mn sorption process on both materials was influenced by diffusion through the boundary layer and intraparticle diffusion. The differences in removal efficiency and rate of $\mathrm{Mn}$ sorption in the temperature range of $10-25{ }^{\circ} \mathrm{C}$ were not found.
\end{abstract}

Keywords: manganese removal; saponite; hematite; andesine; pseudo-first order; pseudo-second order; Elovich model; liquid film diffusion model; intraparticle diffusion kinetic model

\section{Introduction}

Natural mineral materials are widely applied in environmental engineering especially for soil remediation [1,2]. They are also used for water and wastewater treatment fundamentally as filtering beds [3-5]. Natural mineral materials are often used as adsorbents and ion exchangers [6-11], but also as coagulant aids [12,13] or deacidifying media [14]. Along with technical development the variety of mined minerals increases, while research methods for characterizing their properties are being developed. This results in diversity and precision of technological applications of minerals with specific properties.

Groundwater treatment technology is based on using mineral materials. The main metals and compounds removed from groundwater are iron, manganese, ammonium ion and hydrogen sulphide. Applying the various types of materials consisting of and coated with $\mathrm{MnO}_{\mathrm{x}}$ is recognized in various technical solutions including mechanical, chemical and biological processes of contaminations removal [15]. These technologies are related to the granular filter media and the redox processes. An alternative approach, especially for manganese removal, may be adsorption-based fluidized bed 
technology. Here it is also possible to use rock material, such as powdered clay minerals, zeolites or others. Clay minerals and zeolites are known for their high adsorption ability to remove heavy metals or ammonium ions [16-21]. Additionally, metal oxides, frequent components of soils and rocks, are also good adsorbents for heavy and transition metals removal [22,23]. The modification of clay minerals like smectites by iron or aluminum oxides leads to obtaining pillared materials with increased adsorption capacity [24].

However, in nature, it is also possible for such minerals to co-exist. The Ukrainian volcanic tuff from Ivanodolinsky quarry consists mainly of saponite and hematite [25], which provides the basis for research work to assess its adsorption properties for possible environmental applications. Natural materials may show mineral diversity within the deposit, therefore the production of synthetic minerals with repeatable and simultaneously modified properties is also a popular trend [21]. In the Ivanodolinsky quarry, tuffs occur together with basalt rock [25] and study of the properties of this rock is equally needed. Due to the lower price, unmodified natural materials are often tested for their ability to remove pollutants, especially as they are available locally $[1,9,11,19,26]$.

Saponites are rated as a good low-cost sorbents for water purification from heavy metals [27]. As they are characterized by the ability of cation exchange, including ammonium ion, they are considered as the materials with potential use in water treatment [21,28]. Additionally the saponite's active centers can be heterogeneous as a result of coexisting other minerals, e.g., hematite [28]. These are the essential features of the material in terms of its practical application. The more that, the saponite can be effectively separated from water by the electrochemical method [29-31], which confirms the possibility of its use in fluidized bed reactors. However, when analysing the review $[6,21]$ and research works $[24,27,28,31-33]$ on the sorption of inorganic pollutants on smectites, it can be noticed that the researchers focus on removing the following ingredients: $\mathrm{Cd}, \mathrm{Cr}, \mathrm{Cu}, \mathrm{Hg}, \mathrm{Li}, \mathrm{Na}, \mathrm{Ni}, \mathrm{Pb}, \mathrm{Zn}$, as well as the ammonium ion or radionuclides. Work on the removal of $\mathrm{Mn}$ on a saponite is definitely less common, although this removal is of course possible [33]. Due to the common Mn occurrence in groundwater and considering the use of saponite rock in groundwater treatment, the studies on $\mathrm{Mn}$ sorption seems to be necessary.

The sorption process is characterized in equilibrium and by the description of its kinetics. Kinetics and sorption equilibrium studies have been gaining popularity in recent decades and are the subject of many publications $[6,14,26,34,35]$. In literature, there are huge numbers of models enabling description of sorption kinetics. They may be divided into two basic groups: models based on chemical reaction order and models based on molecules diffusion. The most often found kinetic models based on reaction order are pseudo-first order (PFO), proposed by Lagergren [36] and pseudo-second kinetic model (PSO), also called Ho model [37]. The Elovich Equation neglects desorption and is known to describe chemisorption well [38,39]. The less common are models based on molecules diffusion: liquid film diffusion (IFM) [40] and intraparticle diffusion model (IPD) [41] broadening the scope of the sorption mechanism assessment. The temperature of the system in equilibrium studies is differentiated because of the evaluation of thermodynamic parameters. One of the research factors often applied in kinetics sorption studies is concentration of the contamination in the solution and dosage of adsorbent, but the influence of temperature on the kinetics is rarely analyzed. It is often tested at one temperature, often at room temperature $\left(22-25^{\circ} \mathrm{C}\right)[34,35,42-45]$, but also $30{ }^{\circ} \mathrm{C}$ and even $50{ }^{\circ} \mathrm{C}$ [6]. However, the temperature influences the adsorption rate of metal cations on inorganic sorbents and is important in the course of kinetic process [6]. As experimentally demonstrated, at low temperature $\left(3-10^{\circ} \mathrm{C}\right)$ the sorption efficiency on some mineral materials (halloysite, limestone sand, zeolite, diatomite) may decrease, especially in the case of the removal of the heavy metals [46]. The study of the temperature factor seems to be particularly important for the environmental applications of sorption materials, especially for groundwater treatment, which is the naturally cold water.

The study aimed to determine the nature of the kinetics of the manganese sorption process on Ukrainian tuff and basalt at different temperatures characteristic of the natural water environment. The scope of the research included manganese sorption kinetic test on natural mineral sorbents at 
temperatures of $10,17.5$ and $25^{\circ} \mathrm{C}$ in slightly acidic conditions. Sorption and diffusion kinetic models were used in the analysis of test results.

\section{Materials and Methods}

\subsection{Preparation of Minerals}

The volcanic tuff and basalt from the Ivanodolinsky quarry (Rivne region, Ukraine) were investigated. Both materials were used in the raw form and the physically bound water wasn't removed since the experiment covered the conditions for the practical use of minerals without thermal treatment. The materials were used in the form of powder. At the beginning they were grounded, then sieved to obtain a particle size lower than $0.1 \mathrm{~mm}$.

\subsection{Determination the Point of Zero Charge}

The point of zero charge $\mathrm{pH}\left(\mathrm{pH}_{\mathrm{PZC}}\right)$ of materials tested was determined by the batch equilibration [34,47]. Accordingly, the samples of air-dried materials ( $0.2 \mathrm{~g})$ were shaken in PVC vials for $24 \mathrm{~h}$ with $40 \mathrm{~mL}$ of 0.01 and $0.1 \mathrm{~mol} / \mathrm{L} \mathrm{KNO}_{3}$, at different $\mathrm{pH}$ values in the range 2.0-11.0. Initial $\mathrm{pH}$ values were obtained by adding an amount of $\mathrm{KOH}$ or $\mathrm{HNO}_{3}$ solution $(0.1 \mathrm{~mol} / \mathrm{L})$. Determination of the point of zero charge was performed in duplicate, and the mean values were presented. Hach HQ40D-Multimeter with gel electrode (Hach Company, Loveland, CO, USA)) was used to mark $\mathrm{pH}$ of the sample.

\subsection{Adsorption Kinetics Experiment}

The kinetic experiment was carried out by a batch method at temperatures of 10, 17.5 and $25 \pm 0.1^{\circ} \mathrm{C}$. Two liters of a $\mathrm{MnCl}_{2}$ solution in double-distilled water with $\mathrm{Mn}$ concentration of $10 \mathrm{mg} / \mathrm{L}$ and a $\mathrm{pH} 6.0$ were prepared. Then $2.0 \mathrm{~g}$ of the air-dried mineral material was added to the solution and it was kept mixed. At set time intervals, samples of $10 \mathrm{~mL}$ were taken to analyze the Mn concentration. The mineral powder was separated from the solution by two-minute centrifugation (10,000 rpm). The samples of the tested sorbents were collected after the time ranging from 5 to $100 \mathrm{~min}$. Atomic absorption spectrophotometer AA990 (PG Instruments Ltd., Wibtoft, Leicestershire, UK) was used to determine the Mn concentration in solution. HQ40D-Multimeter with gel electrode was used to mark $\mathrm{pH}$ of the sample. Kinetics experiments were realized in duplicate series.

The concentrations of $\mathrm{Mn}$ retained in sorbent phase in time were calculated from the following expression (Equation (1)):

$$
q_{t}=\frac{\left(C_{0}-C_{t}\right) \cdot V}{m}
$$

The removal efficiency of Mn was calculated from the following expression (Equation (2)):

$$
\text { R.E. }=\frac{C_{0}-C_{e}}{C_{0}} \cdot 100 \%
$$

\subsection{Kinetics Models}

The kinetic equations (Equations (3)-(10)) used in the work are presented in the Table 1. The PFO and PSO models have been applied in general form (nonlinear model). As shown in many works $[37,39,48]$ regression analyses using linearized function of originally nonlinear PFO and PSO models often lead to incorrect results and false conclusions. 
Table 1. Equations of the applied kinetic models.

\begin{tabular}{ccc}
\hline Model & Equation & References \\
\hline \multicolumn{3}{c}{ Models based on chemical reaction order } \\
\hline PFO & (3) $q_{t}=q_{e}\left(1-e^{-k_{1} t}\right)$ & {$[36]$} \\
\hline PSO & $(4) q_{t}=\frac{q_{e}^{2} k_{2} t}{1+q_{e} k_{2} t}$ & {$[37]$} \\
& (5) $R_{w}=\frac{1}{1+k_{2} q_{e} t_{\text {ref }}}$ & {$[49]$} \\
\hline \multirow{2}{*}{ Elovich } & (6) $q_{t}=\frac{1}{b} \ln (1+a b \cdot t)$ & {$[38,39]$} \\
& $(7) R_{E}=\frac{1}{q_{\text {ref }} b}$ & {$[50]$} \\
\hline \multirow{3}{*}{ Models based on molecules diffusion } \\
\hline IPD & (8) $\ln (1-F)=-k_{f d} \cdot t$ & {$[40]$} \\
\hline
\end{tabular}

Usually one of mentioned models describes experimental points in a better way which authors mostly confirm by higher coefficient $R^{2}$. Their validities can be determined by the calculation of the standard deviation. The best-fit model is the one with the lowest value of $S D$ (Equation (11)), and the one in which the value of $R^{2}$ is closer to unity. The calculations were made in an Excel spreadsheet using Solver.

$$
S D=\sqrt{\frac{\sum\left[\left(q_{\text {exp }}-q_{c a l}\right) / q_{e}\right]^{2}}{N-1}} \cdot 100
$$

For kinetic models based on the chemical reaction order (PFO, PSO and Elovich models) the error functions were also calculated as follows: the sum of the squares of the errors ERRSQ (Equation (12)), average relative error ARE (Equation (13)), Fisher's test TF (Equation (14)) and chi-square test $\chi^{2}$ (Equation (15)) [51]:

$$
\begin{gathered}
\text { ERRSQ }=\sum_{1}^{N}\left(q_{\text {exp }}-q_{\text {cal }}\right)^{2} \\
\text { ARE }=\frac{100}{N} \sum_{1}^{N}\left|\frac{q_{\text {exp }}-q_{\text {cal }}}{q_{\text {exp }}}\right| \\
T F=\frac{(N-p) \sum_{1}^{N}\left(q_{\text {exp }}-\frac{1}{N} \sum_{1}^{N} q_{\text {exp }}\right)^{2}}{(N-1) \sum\left(q_{\text {exp }}-q_{c a l}\right)^{2}} \\
\chi^{2}=\sum_{1}^{N}\left(\frac{\left(q_{\text {exp }}-q_{c a l}\right)^{2}}{q_{\text {cal }}}\right)
\end{gathered}
$$

\section{Results and Discussion}

\subsection{Characteristics of Minerals}

The minerals have been described as sorbents in our previous studies [25]. Table 2 presents results of the nitrogen adsorption/desorption analysis. Comparing to other natural mineral materials, tuff and basalt are characterized by medium-sized specific surface area, yet the porous structure of tuff is more developed. The XRD analysis showed that volcanic tuff consists of saponite (58\%w/w), quartz (22\%), hematite $(17 \%)$ and a small amount of analcime $(3 \%)$, whereas in basaltic rock consists mainly of 
andesine (93\%), with an admixture of saponite (7\%) [25]. The XRD diagrams of tuff and basalt are shown in Figure 1.

Table 2. Structure parameters of volcanic tuff and basalt from Ivanodolinsky quarry [25].

\begin{tabular}{cccc}
\hline Material & SSA $_{\text {BET }}\left(\mathbf{m}^{2} / \mathbf{g}\right)$ & Total Pore Volume $\left(\mathbf{c m}^{3} / \mathbf{g}\right)$ & Average Pore Radius $(\mathbf{n m})$ \\
\hline Volcanic tuff & 79.3 & 0.113 & 2.76 \\
\hline Basaltic rock & 28.6 & 0.048 & 2.37 \\
\hline
\end{tabular}
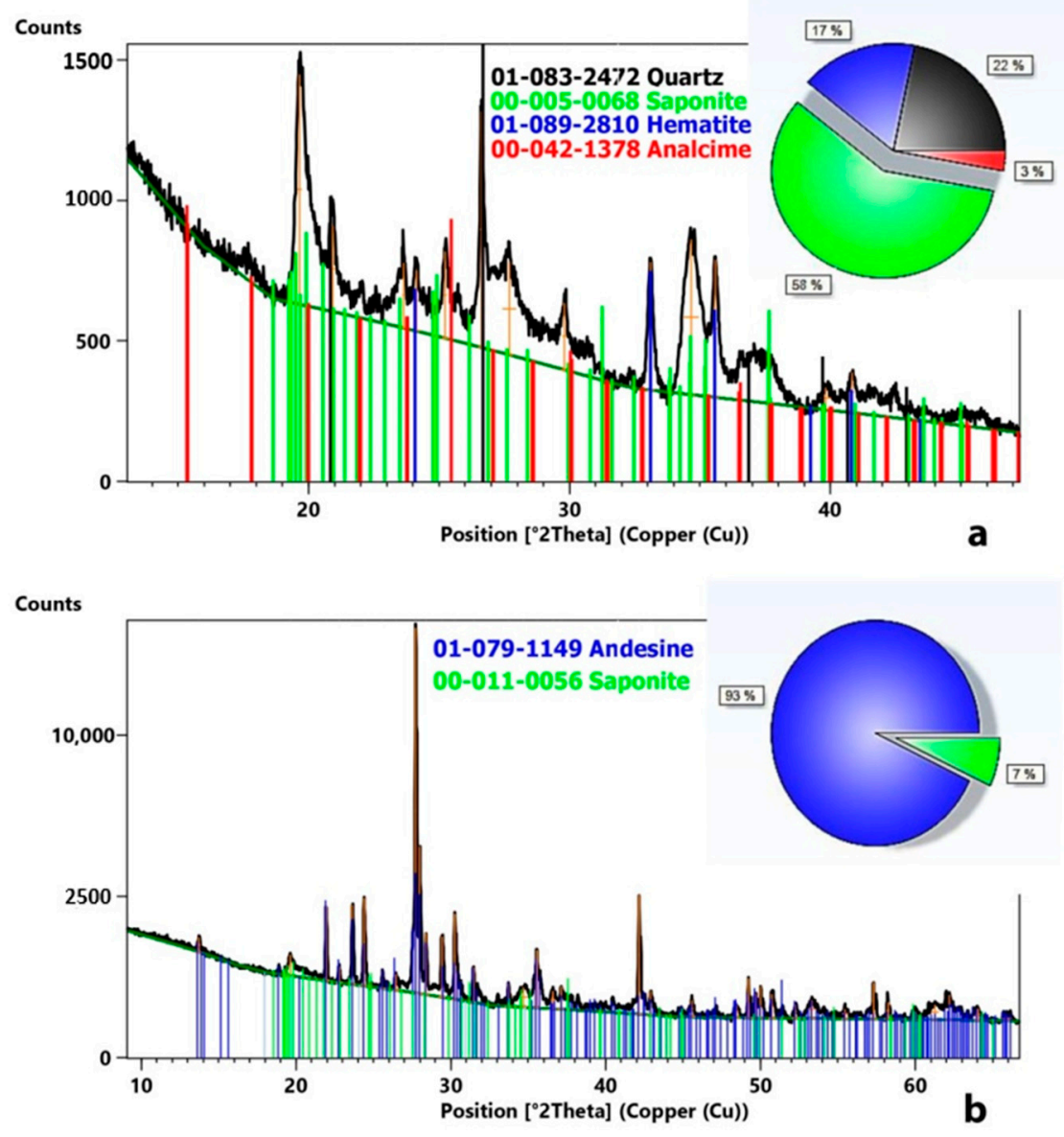

Figure 1. X-ray diffraction patterns of (a) tuff and (b) basalt. Reprinted with permission from Reference [25].

\subsection{Point of Zero Change}

Experimental results of the $\mathrm{pH}_{\mathrm{PZC}}$ determination are illustrated in Figure 2. The $\mathrm{pH}_{\mathrm{PZC}}$ of tuff is at $\mathrm{pH}$ 8.9. This is consistent with the identified $\mathrm{pH}_{\mathrm{PZC}}$ values of the minerals that form it: 8.2 of smectite [52], 6.0 of smectite-rich clay soil [53], 6.5-8.5 of hematite [54] and $<5$ of quartz [54]. The $\mathrm{pH}_{\mathrm{PZC}}$ of Ukrainian basalt rock consists mainly of plagioclase (andesine) equals 8.5. Similar result ( $\mathrm{pH}_{\mathrm{PZC}}$ 7.6) was obtained in the case of volcanic basalt rock from Ethiopia, also rich in plagioclases [34]. By analyzing the research system, the $\mathrm{pH}$ of solution (6.0) was lower than $\mathrm{pH}$ PzC of used sorbents. In this case, the surfaces of aluminosilicate minerals receive a slightly positive charge, because the protonation of silanol groups occurs at very low $\mathrm{pH}$ and only aluminol groups are easy protonated [55]. However, the $\mathrm{pH}$-dependent charge is lesser for smectite and makes up $5-10 \%$ of the surface. Studies on the removal of $\mathrm{Cd}, \mathrm{Pb}$ and $\mathrm{Cu}$ on Turkish smectite have shown that the sorption process is inhibited only in an acidic environment at $\mathrm{pH}<4$ [56]. Only hematite's adsorption properties significantly depends of the $\mathrm{pH}$ of the solution [55]. Therefore, the slightly acidic $\mathrm{pH}$ of the solution, typical for 
groundwater, can a bit adversely affect the adsorption by an electrostatic repulsion, but does not exclude it.
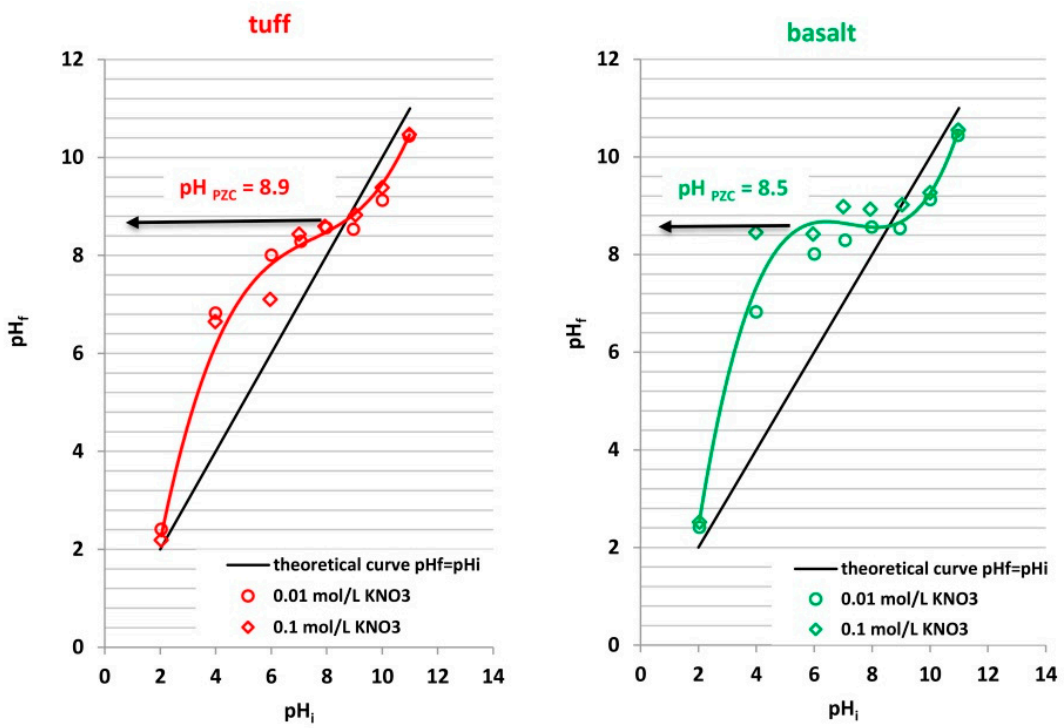

Figure 2. Determination of $\mathrm{pH}_{\mathrm{PZC}}$ of tuff and basalt in $\mathrm{KNO}_{3}$ solutions.

\subsection{Effect of Contact Time}

Figure 3 shows the impact of contact time on Mn ion sorption on tested materials at temperatures of $10,17.5$ and $25^{\circ} \mathrm{C}$. The equilibrium state of Mn sorption on tuff settled in a relatively short time after about $35 \mathrm{~min}$ at all tested temperatures. In the case of basalt, the dynamic equilibrium of $\mathrm{Mn}$ sorption was established after $45 \mathrm{~min}$. During the first $15 \mathrm{~min}$, the Mn sorption process on both tuff and basalt proceeded quickly due to the high availability of active sites on the surface of each of the sorbents tested. They are the favorable results comparing with other minerals characterized by equilibrium adsorption time 30-180 min [6]. Adsorption of $\mathrm{Mn}$ on another rock material Turkish kaolinite, required even up to $120 \mathrm{~min}$ to reach equilibrium [57].

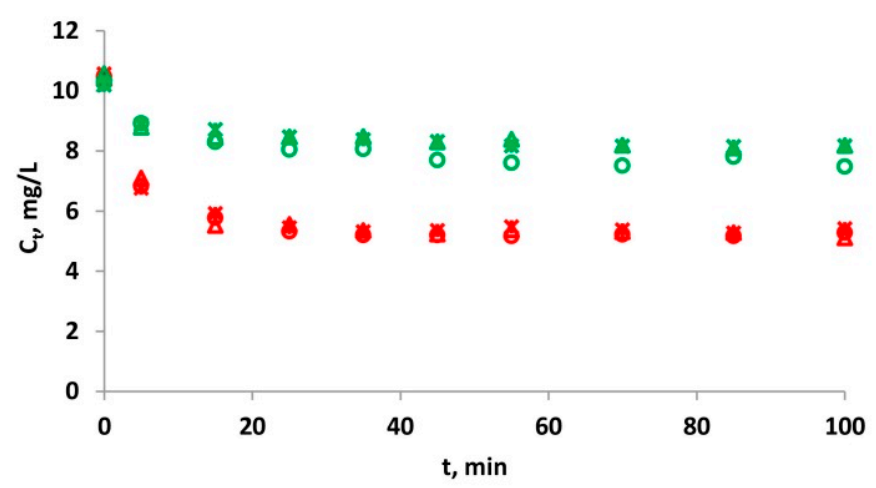

Figure 3. The equilibrium state of Mn sorption on tuff (T) and basalt (B) at temperature 10, 17.5 and $25^{\circ} \mathrm{C}$.

The degree of Mn ion removal efficiency during sorption on tuff and basalt at the temperatures tested is summarized in Table 3. The lowering of Mn concentration at all temperatures tested was higher on tuff, about $50 \%$. In the case of basalt, it was $21.5 \%$. No influence of temperature (in the tested range) on the effectiveness of Mn removal was found. This is beneficial while using these materials for treatment of low temperature water. $\mathrm{pH}$ has been changing during manganese sorption in the Mn-tuff and Mn-basalt systems (Figure 4). Simultaneously with the removal of 
Mn cations from the solution, its $\mathrm{pH}$ was increasing. In both analyzed systems the $\mathrm{pH}$ was rising from 6.0 to 6.5. As stated above, tuff contains a significant amount of saponite, and basalt consists mainly of andesine. Saponite is the phyllosilicate of the smectite group with the chemical formula $\left(\mathrm{Ca}_{0.5}, \mathrm{Na}\right)_{0.3}\left(\mathrm{Mg}, \mathrm{Fe}^{2+}\right)_{3}(\mathrm{Si}, \mathrm{Al})_{4} \mathrm{O}_{10}(\mathrm{OH})_{2} \cdot 4 \mathrm{H}_{2} \mathrm{O}$ and andesine belonging to plagioclases is expressed as $\mathrm{Na}_{0.7-0.5} \mathrm{Ca}_{0.3-0.5} \mathrm{Al}_{1.3-1.5} \mathrm{Si}_{2.7-2.5} \mathrm{O}_{8}$ [58]. Changes in $\mathrm{pH}$ may indicate that the alkali and alkaline earth metals present in the minerals are exchanged with the $\mathrm{Mn}$ present in the solution. The $\mathrm{MnCl}_{2}$, salt of weak base and strong acid, dissociates in water and causes $\mathrm{pH}<7$ (6.0). When $\mathrm{Mn}$ is exchanged for $\mathrm{Ca}$ and $\mathrm{Na}$, salts of strong bases and strong acids begin to dominate in the solution, and the $\mathrm{pH}$ tends to 7. The increase in $\mathrm{pH}$ may also be partly due to the dissolution of the alkaline components of the rock, not associated with Mn removal. This applies to basalt, the series of which is ascending and not flattened like a kinetic curve. From a technological point of view, a slight increase in water $\mathrm{pH}$ is acceptable.

Table 3. R.E. of Mn sorption on tuff and basalt at $10,17.5$ and $25^{\circ} \mathrm{C}$ in a state of equilibrium (tuff- $35 \mathrm{~min}$, basalt-45 $\mathrm{min})$.

\begin{tabular}{cccc}
\hline \multicolumn{4}{c}{ R.E., \% } \\
\hline Material & $\mathbf{1 0}{ }^{\circ} \mathbf{C}$ & $\mathbf{1 7 . 5}{ }^{\circ} \mathbf{C}$ & $\mathbf{2 5}{ }^{\circ} \mathbf{C}$ \\
Tuff & 50.4 & 48.6 & 49.7 \\
Basalt & 21.4 & 21.5 & 21.5 \\
\hline
\end{tabular}

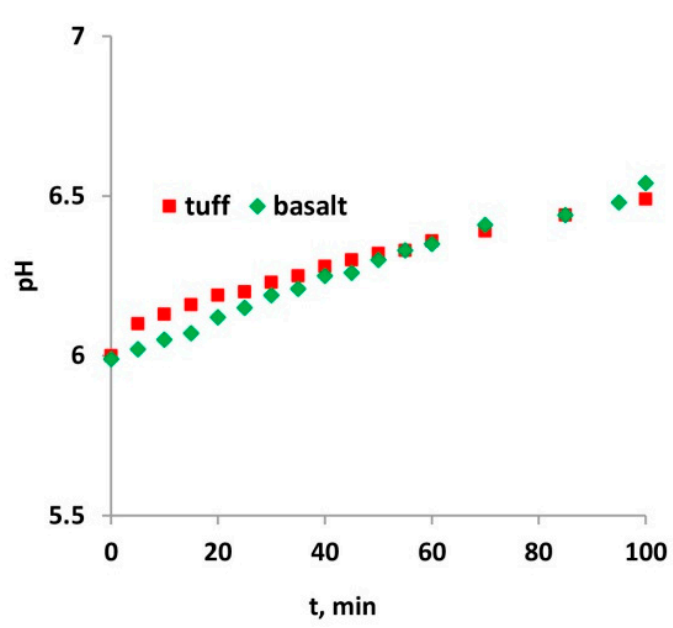

Figure 4. Changes of $\mathrm{pH}$ in the solution during Mn sorption on the tested materials.

\subsection{Models Based on Chemical Reaction Order}

Figure 5 shows the experimental data of the sorption of Mn on tuff and basalt at the tested temperatures together with the curves calculated from the three kinetic models based on reaction order (pseudo-first order, pseudo-second order and Elovich models). Points from the equilibrium area were excluded when experimental results were fitted by models [39,59]. It was found that PSO equation is superior to other two ones for the description of kinetic data. The fitness is justified based on the fact that $R^{2}$ are within $0.8528-0.9918$ and $0.8375-0.9354$, respectively (Table 4 ). At the same time, analyzing the $S D$ standard values for Mn sorption kinetics models on the tested tuff and basalt materials, the low $S D$ values obtained for the PSO and Elovich models indicate a better fit of the experimental data with the pseudo-second order kinetics model. This [60] could suggested chemical nature of the sorption of Mn on tuff and basalt. Similar phenomena has been observed for various mineral materials $[6,16,34,61]$. 


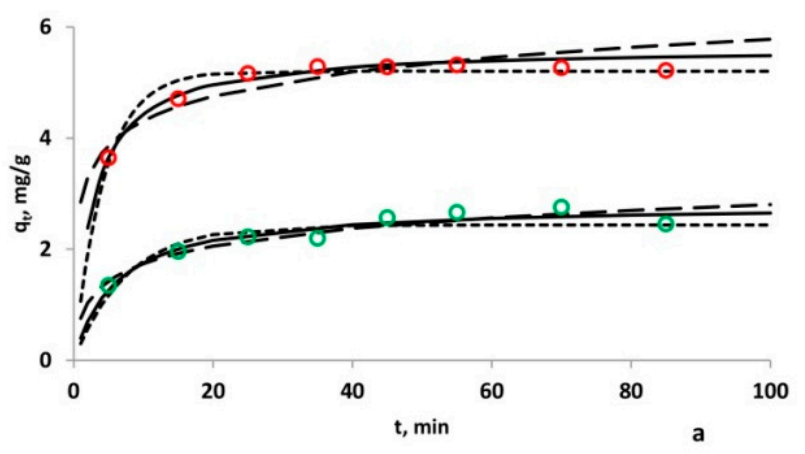

OT $10^{\circ} \mathrm{C}$ OB $10^{\circ} \mathrm{C}$

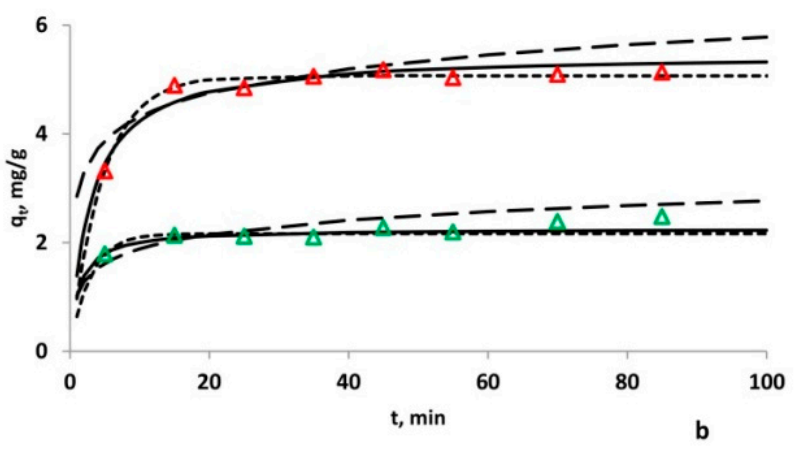

$\Delta T 17.5^{\circ} \mathrm{C} \quad \Delta B 17.5^{\circ} \mathrm{C}$

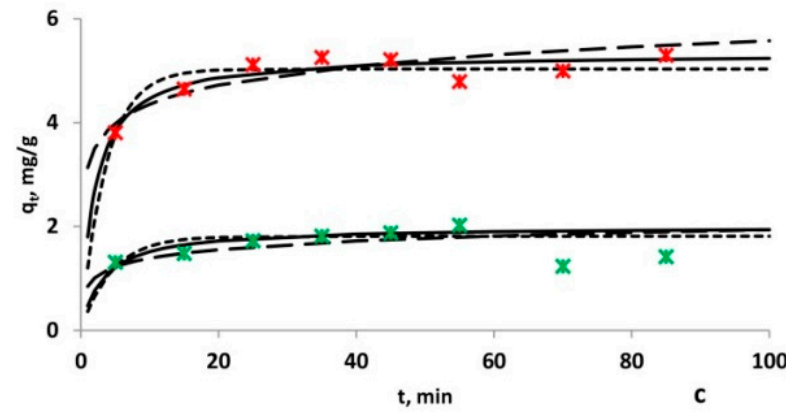

$\times T 25^{\circ} \mathrm{C} \times B 25^{\circ} \mathrm{C}$

Figure 5. Regression analysis of the sorption on Mn on tuff and basalt by PFO (dashed line), PSO (solid line) and Elovich (dotted line) models.

The error functions used for the reaction-order models (Equations (12)-(15)) confirm that the PSO model best approximates the experimental data. However, the coefficient of determination $R^{2}$ does not always give an unequivocal result; sometimes between individual model the insignificant differences make it difficult to unambiguously analyze and indicate a specific model. As shown by Chutkowski et al. [51], relying on one selected optimization criterion may result in the risk of incorrect indication of the optimal sorption kinetics model. The parallel occurrence of several other errors can eliminate the risk of making mistakes. The results of applied error functions (ERRSQ, ARE, TF and $\chi^{2}$ ) presented in Table 4 made it possible to confirm the course of sorption in accordance with the PSO model. 
Table 4. Parameters of sorption kinetics models based on reaction order, characterized by coefficient of determination, standard deviation and the error functions.

\begin{tabular}{|c|c|c|c|c|c|c|c|c|c|}
\hline \multicolumn{10}{|c|}{ Tuff } \\
\hline PFO Model & $\begin{array}{c}q_{e} \\
\mathrm{mg} / \mathrm{g}\end{array}$ & $\begin{array}{c}k_{1} \\
1 / \mathrm{min}\end{array}$ & $R^{2}$ & $S D$ & & ERRSQ & ARE & TF & $x^{2}$ \\
\hline $10^{\circ} \mathrm{C}$ & 5.2 & 0.23 & 0.9362 & 0.036 & & 0.1418 & 2.5373 & 12.0966 & 0.0288 \\
\hline $17.5^{\circ} \mathrm{C}$ & 5.1 & 0.21 & 0.9404 & 0.021 & & 0.0529 & 1.3014 & 36.9299 & 0.0105 \\
\hline $25^{\circ} \mathrm{C}$ & 5.0 & 0.27 & 0.8177 & 0.046 & & 0.2478 & 3.7851 & 4.8286 & 0.0498 \\
\hline PSO Model & $\begin{array}{c}q_{e} \\
\mathrm{mg} / \mathrm{g}\end{array}$ & $\begin{array}{c}k_{2} \\
\mathrm{~g} /(\mathrm{mg} \cdot \min )\end{array}$ & $R^{2}$ & $S D$ & $\boldsymbol{R}_{W}$ & ERRSQ & ARE & TF & $x^{2}$ \\
\hline $10^{\circ} \mathrm{C}$ & 5.6 & 0.065 & 0.9918 & 0.012 & 0.01 & 0.0177 & 0.9335 & 97.1013 & 0.0035 \\
\hline $17.5^{\circ} \mathrm{C}$ & 5.5 & 0.062 & 0.9791 & 0.037 & 0.02 & 0.1469 & 2.6028 & 13.3081 & 0.0326 \\
\hline $25^{\circ} \mathrm{C}$ & 5.3 & 0.095 & 0.8528 & 0.043 & 0.01 & 0.2203 & 3.1705 & 5.4315 & 0.0433 \\
\hline Elovich Model & $\begin{array}{c}a \\
\mathrm{mg} / \mathrm{g} \cdot \min \end{array}$ & $\begin{array}{c}b \\
\mathrm{~g} / \mathrm{mg}\end{array}$ & $R^{2}$ & $S D$ & $\boldsymbol{R}_{E}$ & ERRSQ & ARE & TF & $x^{2}$ \\
\hline $10^{\circ} \mathrm{C}$ & 55.0 & 1.57 & 0.7667 & 0.048 & 0.13 & 0.1800 & 3.2419 & 9.5294 & 0.0394 \\
\hline $17.5^{\circ} \mathrm{C}$ & 101.5 & 1.80 & 0.7881 & 0.087 & 0.11 & 0.5762 & 6.1464 & 3.3932 & 0.1370 \\
\hline $25^{\circ} \mathrm{C}$ & 196.0 & 1.89 & 0.7337 & 0.066 & 0.11 & 0.3984 & 4.5675 & 3.0036 & 0.0797 \\
\hline \multicolumn{10}{|c|}{ Basalt } \\
\hline PFO Model & $\begin{array}{c}q_{e} \\
\mathrm{mg} / \mathrm{g}\end{array}$ & $\begin{array}{c}k_{1} \\
1 / \mathrm{min}\end{array}$ & $R^{2}$ & $S D$ & & ERRSQ & ARE & TF & $x^{2}$ \\
\hline $10^{\circ} \mathrm{C}$ & 2.4 & 0.13 & 0.8537 & 0.094 & & 0.1811 & 8.1872 & 4.9676 & 0.0893 \\
\hline $17.5^{\circ} \mathrm{C}$ & 2.2 & 0.35 & 0.8501 & 0.029 & & 0.0203 & 2.1287 & 5.3365 & 0.0094 \\
\hline $25^{\circ} \mathrm{C}$ & 1.8 & 0.22 & 0.6209 & 0.102 & & 0.1369 & 7.3550 & 2.0458 & 0.0792 \\
\hline PSO Model & $\begin{array}{c}q_{e} \\
\mathrm{mg} / \mathrm{g}\end{array}$ & $\begin{array}{c}k_{2} \\
\mathrm{~g} /(\mathrm{mg} \cdot \min )\end{array}$ & $R^{2}$ & $S D$ & $\boldsymbol{R}_{W}$ & ERRSQ & ARE & TF & $x^{2}$ \\
\hline $10^{\circ} \mathrm{C}$ & 2.8 & 0.059 & 0.9354 & 0.056 & 0.04 & 0.0738 & 4.5153 & 12.1924 & 0.0326 \\
\hline $17.5^{\circ} \mathrm{C}$ & 2.3 & 0.352 & 0.8733 & 0.027 & 0.01 & 0.0172 & 2.0998 & 6.3122 & 0.0079 \\
\hline $25^{\circ} \mathrm{C}$ & 2.0 & 0.131 & 0.8375 & 0.068 & 0.02 & 0.0577 & 4.9277 & 4.8569 & 0.0355 \\
\hline Elovich Model & $\begin{array}{c}a \\
\mathrm{mg} / \mathrm{g} \cdot \min \end{array}$ & $\begin{array}{c}b \\
g / m g\end{array}$ & $R^{2}$ & $S D$ & $R_{E}$ & ERRSQ & ARE & TF & $x^{2}$ \\
\hline $10^{\circ} \mathrm{C}$ & 1.9 & 2.14 & 0.9728 & 0.054 & 0.19 & 0.0626 & 4.3843 & 14.3639 & 0.0279 \\
\hline $17.5^{\circ} \mathrm{C}$ & 5.1 & 2.60 & 0.8382 & 0.120 & 0.18 & 0.2780 & 9.4243 & 0.3897 & 0.1203 \\
\hline $25^{\circ} \mathrm{C}$ & 8.1 & 4.19 & 0.9503 & 0.239 & 0.21 & 0.1072 & 6.5275 & 2.6125 & 0.0634 \\
\hline
\end{tabular}

To present chemisorption the PSO and Elovich models, the approaching equilibrium factors $R_{W}$ and $R_{E}$ were calculated (Table 4). The values of the $R_{w}$ in the Mn-tuff system are in the range 0.01-0.02, while in the Mn-basalt system 0.01-0.04 at applied temperatures. Therefore, in both cases of tuff and basalt are in the range of $0.1>R_{W}>0.01$, which allows classifying the considered sorptive-sorbent system into zone II. That means the equilibrium in both sorption systems is not complicated to achieve [49]. The values of the $R_{E}$ factor are within $0.11-0.13$ and $0.18-0.21$ in the Mn-tuff and Mn-basalt sorption system respectively. They are consistent with the chemical nature of Mn sorption on the both materials. The $R_{E}$ values are in the region of $0.3>R_{E}>0.1$ corresponding to zone II with the curve of sorption with "mildly rising". In contrast to $R_{W}$ the values of $R_{E}$ for basalt are higher at each temperature than those obtained for tuff as sorbent, which confirms that Mn sorption on basalt occurs more slowly than on tuff [50]. Obtained values of reaction rate $k_{2}$ as well as $R_{W}$ and $R_{E}$ factors show no dependence of temperature that means the sorption occurs with the relatively same speed in the range of $10-25^{\circ} \mathrm{C}$.

\subsection{Diffusion Kinetic Models}

Liquid film diffusion model is applicable at slow processes of adsorbate flow through the liquid film surrounding the adsorbent particles, which determines kinetics of the process [40]. A linear plot of $\ln \left(1-q_{t} / q_{e}\right)$ vs. $t$ with zero intercepts suggests that adsorption kinetics is controlled by a diffusion 
through liquid film surrounding the solid sorbents. The $k_{f d}$ was calculated from the slope of the straight line plot and its values are presented in Figure 6, along with $R^{2}$. The similarity to the unity value of $R^{2}$ (0.8154-0.9365) for tuff and (0.7921-0.9526) for basalt respectively indicated an adequate fitting of film diffusion model. However, the straight lines did not pass through the origin thereby suggesting that film diffusion might not be the sole rate-limiting step [62,63].
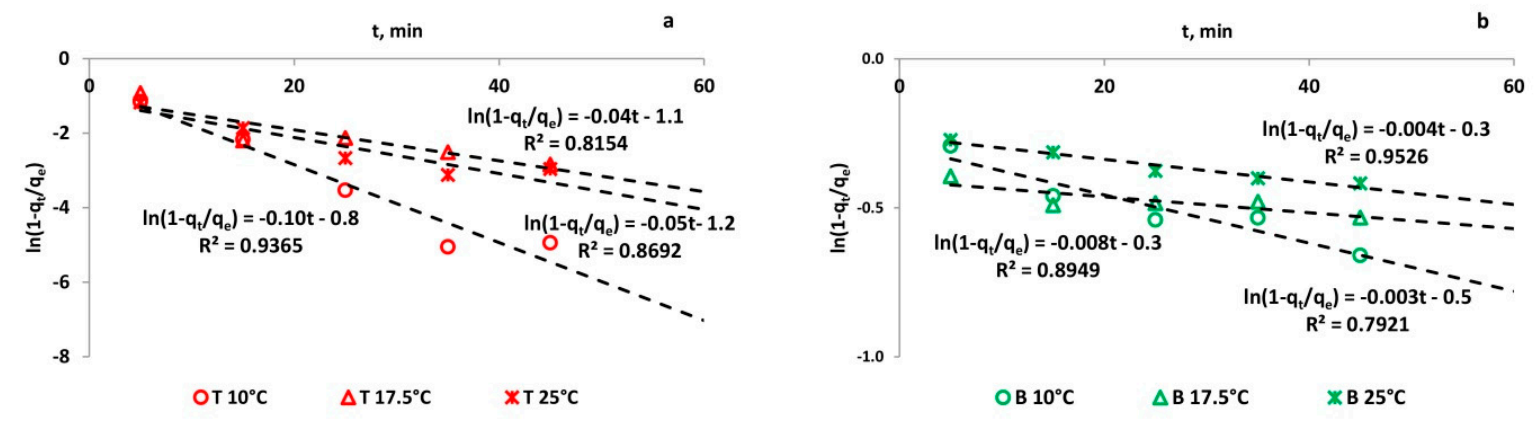

Figure 6. Liquid film diffusion kinetic plot for Mn sorption on: (a) tuff and (b) basalt.

The mass transfer into the interior of the particle, characterized by an intraparticle diffusion coefficient, can be the slowest step. The most commonly used is the intraparticle diffusion model (IPD) of Weber and Morris. The IDP model for Mn on tuff and basalt is shown in Figure 7. The slope of the plots gave the values of $k_{i}$ presented in Table 5 . The plots are not linear over the whole time range, indicating that more than one step is involved in the sorption of Mn on tuff and basalt. The intraparticle diffusion kinetic plots in fragmented form showed two types of linearity indicating two diffusion stages of Mn adsorption onto tuff and basalt. For Mn sorption on both tuff and basalt, at tested temperature range the first stage plot passed near the origin, whereas the second one did not. It was concluded that the second stage was controlled by both film and intraparticle diffusions. For Mn sorption on both mineral sorbents, at all temperatures tested, the $k_{i 1}>k_{i 2}$ was attributed to the faster rate of film diffusion than intraparticle diffusion. It was concluded that the sorption kinetics might be controlled by film diffusion and intraparticle diffusion simultaneously.
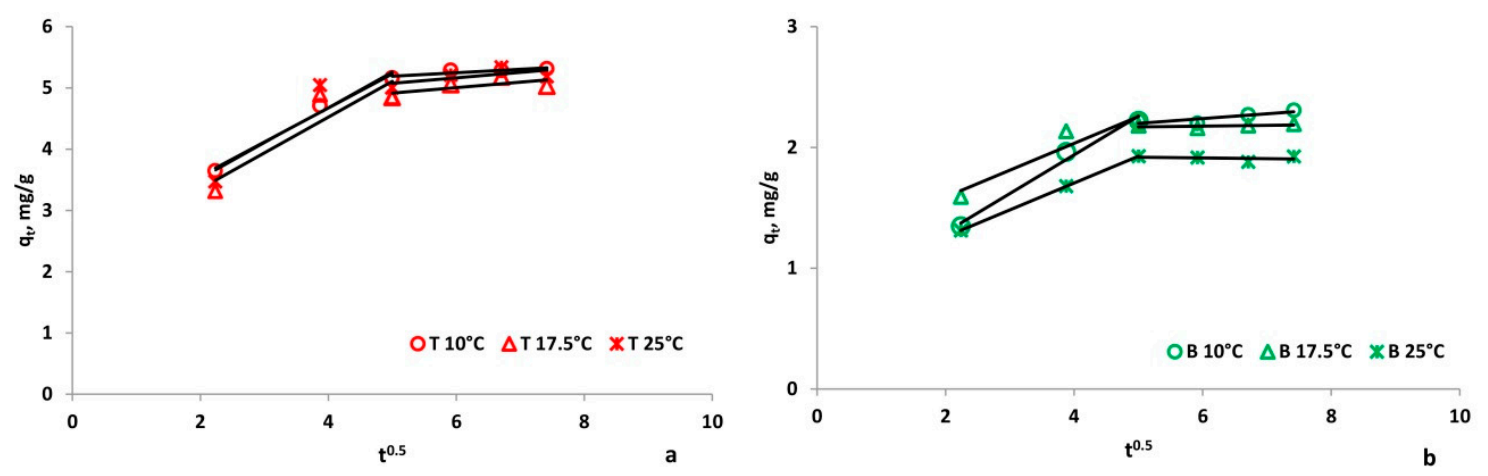

Figure 7. Intraparticle diffusion kinetic plot for Mn sorption on: (a) tuff (T) and (b) basalt (B) in fragmented form. 
Table 5. Parameters of intraparticle diffusion model, characterized by coefficient of determination and standard deviation.

\begin{tabular}{|c|c|c|c|c|c|c|c|c|}
\hline Temperature & $\begin{array}{c}k_{i 1} \\
\mathrm{mg} / \mathrm{g} \cdot \min ^{0.5}\end{array}$ & $\begin{array}{c}c_{i 1} \\
\mathrm{mg} / \mathrm{g}\end{array}$ & $R^{2}$ & $S D$ & $\begin{array}{c}k_{i 2} \\
\mathrm{mg} / \mathrm{g} \cdot \min ^{0.5}\end{array}$ & $\begin{array}{c}c_{i 2} \\
\mathrm{mg} / \mathrm{g}\end{array}$ & $R^{2}$ & $S D$ \\
\hline \multicolumn{9}{|c|}{ Tuff } \\
\hline & 0.56 & 2.45 & 0.9852 & 0.002 & 0.06 & 4.91 & 0.7885 & 0.006 \\
\hline $17.5^{\circ} \mathrm{C}$ & 0.58 & 2.18 & 0.8179 & 0.094 & 0.09 & 4.47 & 0.4602 & 0.020 \\
\hline $25{ }^{\circ} \mathrm{C}$ & 0.58 & 2.34 & 0.8179 & 0.081 & 0.09 & 4.63 & 0.4600 & 0.019 \\
\hline \multicolumn{9}{|c|}{ Basalt } \\
\hline $10{ }^{\circ} \mathrm{C}$ & 0.33 & 0.62 & 0.9847 & 0.028 & 0.04 & 2.00 & 0.7198 & 0.012 \\
\hline $17.5^{\circ} \mathrm{C}$ & 0.23 & 1.10 & 0.8515 & 0.005 & 0.01 & 2.14 & 0.2515 & 0.005 \\
\hline $25^{\circ} \mathrm{C}$ & 0.22 & 0.81 & 0.9999 & 0.001 & 0.12 & 1.12 & 0.0849 & 0.075 \\
\hline
\end{tabular}

\section{Conclusions}

The Mn sorption process on both tuff and basalt proceeded quickly and the dynamic equilibrium state was achieved after 35 and 45 min respectively. Although the process took place in a slightly acidic environment and below $\mathrm{pH}_{\mathrm{PZC}}$ of the sorbents, possible electrostatic repulsion did not inhibit the removal of Mn. During the kinetic studies the systems reached the equilibrium and in this state the sorption capacity of the tuff was twice as high as on the basalt $(5.5 \mathrm{mg} / \mathrm{g}$ and $2.4 \mathrm{mg} / \mathrm{g}$ respectively). The better sorption properties of the tuff was due of high content of saponite $(58 \% w / w)$, the layered mineral from the smectite group characterized by ion-exchange properties, as well as hematite $(17 \%)$ the well-known metals sorbent.

The Mn sorption on both materials follows the PSO kinetics model. Based on $R_{W}$ factor values in both sorption systems the achievement of equilibrium is not complicated. The reaction rate $k_{2}$ and $R_{E}$ factor confirm that Mn sorption on basalt occurs more slowly than on tuff. Research has shown that in the temperature range of $10-25^{\circ} \mathrm{C}$ there are no differences in removal efficiency and rate of Mn sorption. This is beneficial while using these materials for treatment of low temperature water. Based on the diffusion kinetic models, it was determined that Mn sorption process on both materials is influenced by diffusion through the boundary layer and intraparticle diffusion.

Author Contributions: L.R.-Conceptualization, formal analysis, methodology, visualization, writing-original draft; M.M.M.-conceptualization, investigation, methodology, visualization, writing-review and editing; Y.T.-conceptualization, investigation, methodology, writing-original draft; T.S.—conceptualization, formal analysis, writing - review and editing; M.T.-O.--investigation, resources. All authors have read and agreed to the published version of the manuscript.

Funding: This research received no external funding.

Acknowledgments: We acknowledge Alina Kiedryńska for help in editing in English version of the article.

Conflicts of Interest: The authors declare no conflict of interest.

\section{Nomenclature}

a initial sorption rate, $\mathrm{mg} / \mathrm{g} \cdot \mathrm{min}$

ARE average relative error

$b$ desorption constant related to the extent of surface coverage and activation energy for

chemisorption, $\mathrm{g} / \mathrm{mg}$

B basalt

$c_{i} \quad$ intercept of IPD model, $\mathrm{mg} / \mathrm{g}$

$\mathrm{C}_{0} \quad$ initial concentration of $\mathrm{Mn}, \mathrm{mg} / \mathrm{L}$

$\mathrm{C}_{e} \quad$ equilibrium concentration of $\mathrm{Mn}, \mathrm{mg} / \mathrm{L}$

$C_{t} \quad$ concentration of $\mathrm{Mn}$ at defined time, $\mathrm{mg} / \mathrm{L}$

ERRSQ the sum of the squares of the errors 


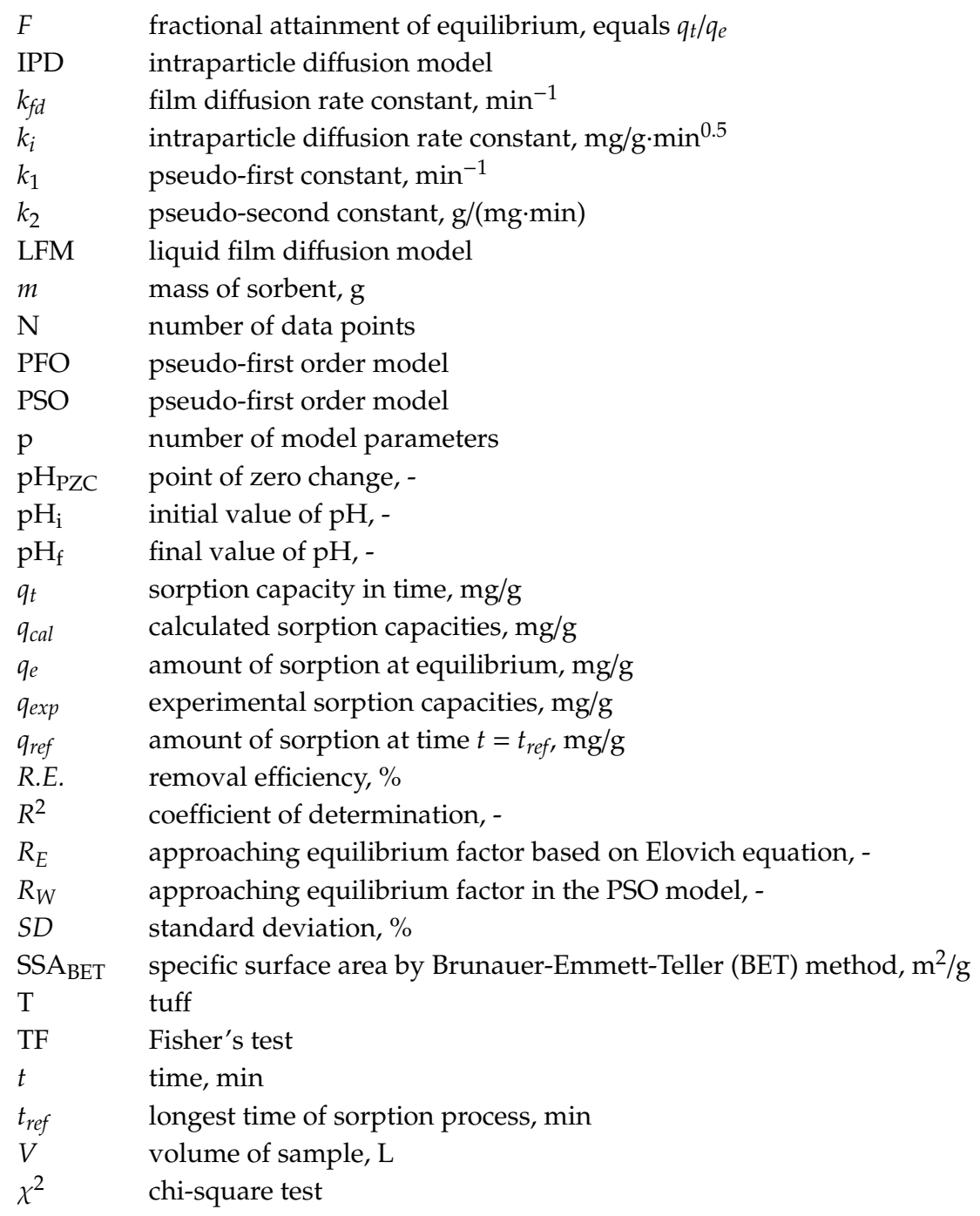

\section{References}

1. Tangviroon, P.; Noto, K.; Igarashi, T.; Kawashima, T.; Ito, M.; Sato, T.; Mufalo, W.; Chirwa, M.; Nyambe, I.; Nakata, H.; et al. Immobilization of lead and zinc leached from mining residual materials in Kabwe, Zambia: Possibility of Chemical Immobilization by Dolomite, Calcined Dolomite, and Magnesium Oxide. Minerals 2020, 10, 763. [CrossRef]

2. Radziemska, M.; Bęś, A.; Gusiatin, Z.M.; Majewski, G.; Mazur, Z.; Bilgin, A.; Jaskulska, I.; Brtnický, M. Immobilization of potentially toxic elements (PTE) by mineral-based amendments: Remediation of contaminated soils in post-industrial sites. Minerals 2020, 10, 87. [CrossRef]

3. Siwiec, T. The sphericity of grains of filtration beds applied for water treatment on examples of selected minerals. Electron. J. Pol. Agric. Univ. 2007, 10, 1-30.

4. Filtration Materials for Groundwater: A Guide to Good Practice; Kozyatnyk, I. (Ed.) IWA Publishing: London, UK, 2016; ISBN 978-1-78040-699-2.

5. Rizzo, A.; Bresciani, R.; Martinuzzi, N.; Masi, F. Online monitoring of a long-term full-scale constructed wetland for the treatment of winery wastewater in Italy. Appl. Sci. 2020, 10, 555. [CrossRef]

6. Sen Gupta, S.; Bhattacharyya, K.G. Kinetics of adsorption of metal ions on inorganic materials: A review. Adv. Colloid Interface Sci. 2011, 162, 39-58. [CrossRef]

7. Adeyemo, A.A.; Adeoye, I.O.; Bello, O.S. Adsorption of dyes using different types of clay: A review. Appl. Water Sci. 2017, 7, 543-568. [CrossRef]

8. Jiang, N.; Shang, R.; Heijman, S.G.J.; Rietveld, L.C. High-silica zeolites for adsorption of organic micro-pollutants in water treatment: A review. Water Res. 2018, 144, 145-161. [CrossRef] 
9. Alshameri, A.; Xinghu, W.; Dawood, A.; Assabri, A.; Xin, C.; Yan, C. Characterization of Yemeni natural zeolite (Al-Ahyuq Area) and its environment applications: A review. J. Ecol. Eng. 2019, 20, 157-166. [CrossRef]

10. Weidner, E.; Ciesielczyk, F. Removal of hazardous oxyanions from the environment using metal-oxide-based materials. Materials 2019, 12, 927. [CrossRef]

11. Wazwaz, A.; Al-Salaymeh, A.; Khan, M.S. Removing heavy metals through different types of soils and marble powder found in Oman. J. Ecol. Eng. 2019, 20, 136-142. [CrossRef]

12. Aygun, A.; Yilmaz, T. Improvement of coagulation-flocculation process for treatment of detergent wastewaters using coagulant aids. Int. J. Chem. Environ. Eng. 2011, 1, 97-101.

13. Hendricks, D. Fundamentals of Water Treatment Unit Processes: Physical, Chemical, and Biological; CRC Press: Cleveland, OH, USA, 2011; ISBN 978-1-4200-6192-5.

14. Greiserman, M.; Hasson, D.; Semiat, R.; Shemer, H. Kinetics of dolomite dissolution in a packed bed by acidified desalinated water. Desalination 2016, 396, 39-47. [CrossRef]

15. Michel, M.M.; Reczek, L.; Papciak, D.; Włodarczyk-Makuła, M.; Siwiec, T.; Trach, Y. Mineral Materials coated with and consisting of $\mathrm{MnO}_{\mathrm{x}}$ — characteristics and application of filter media for groundwater treatment: A review. Materials 2020, 13, 2232. [CrossRef] [PubMed]

16. Taffarel, S.R.; Rubio, J. Removal of $\mathrm{Mn}^{2+}$ from aqueous solution by manganese oxide coated zeolite. Miner. Eng. 2010, 23, 1131-1138. [CrossRef]

17. Belchinskaya, L.; Novikova, L.; Khokhlov, V.; Ly Tkhi, J. Contribution of ion-exchange and non-ion-exchange reactions to sorption of ammonium ions by natural and activated aluminosilicate sorbent. J. Appl. Chem. 2013, 2013, 789410. [CrossRef]

18. Filatova, E.G.; Pozhidaev, Y.N.; Pomazkina, O.I. Investigation of adsorption of heavy metal ions by natural aluminosilicate. Prot. Met. Phys. Chem. Surf. 2016, 52, 438-442. [CrossRef]

19. Kadja, G.T.M.; Ilmi, M.M. Indonesia natural mineral for heavy metal adsorption: A review. JESSD $2019,2$. [CrossRef]

20. Mary Ugwu, I.; Anthony Igbokwe, O. Sorption of heavy metals on clay minerals and oxides: A review. In Advanced Sorption Process Applications; Edebali, S., Ed.; IntechOpen: London, UK, 2019; ISBN 978-1-78984-818-2.

21. Zhou, C.H.; Zhou, Q.; Wu, Q.Q.; Petit, S.; Jiang, X.C.; Xia, S.T.; Li, C.S.; Yu, W.H. Modification, hybridization and applications of saponite: An overview. Appl. Clay Sci. 2019, 168, 136-154. [CrossRef]

22. Hua, M.; Zhang, S.; Pan, B.; Zhang, W.; Lv, L.; Zhang, Q. Heavy metal removal from water/wastewater by nanosized metal oxides: A review. J. Hazard. Mater. 2012, 211-212, 317-331. [CrossRef]

23. Wang, X.; Dong, W.; Tao, Z. A multitracer study on the adsorption of 32 elements on a natural hematite $\left(\alpha-\mathrm{Fe}_{2} \mathrm{O}_{3}\right)$ : Effects of $\mathrm{pH}$ and fulvic acid. Colloid Surf. Physicochem. Eng. Asp. 2003, 223, 135-143. [CrossRef]

24. Franco, F.; Benítez-Guerrero, M.; Gonzalez-Triviño, I.; Pérez-Recuerda, R.; Assiego, C.; Cifuentes-Melchor, J.; Pascual-Cosp, J. Low-cost aluminum and iron oxides supported on dioctahedral and trioctahedral smectites: A comparative study of the effectiveness on the heavy metal adsorption from water. Appl. Clay Sci. 2016, 119, 321-332. [CrossRef]

25. Melnychuk, V.; Trach, Y.; Kosinov, V.; Michel, M.M.; Reczek, L. Research of the mineral complex and opportunities using basalts and tuffs of Ivanodolinsky quarry of the Rivne region in water treatment. Probl. Water Supply Sew Hydraul. Sci. Tech. J. 2018, 30, 36-47.

26. Puszkarewicz, A.; Kaleta, J. Adsorption of chromium(VI) on raw and modified Carpathian diatomite. J. Ecol. Eng. 2019, 20, 11-17. [CrossRef]

27. Petra, L.; Billik, P.; Melichová, Z.; Komadel, P. Mechanochemically activated saponite as materials for $\mathrm{Cu}^{2+}$ and $\mathrm{Ni}^{2+}$ removal from aqueous solutions. Appl. Clay Sci. 2017, 143, 22-28. [CrossRef]

28. Polyakov, V.E.; Tarasevich, Y.I. Ion-exchange equilibriums involving single-charged cations on saponite. J. Water Chem. Technol. 2012, 34, 11-16. [CrossRef]

29. Minenko, V.G. Justification and design of electrochemical recovery of saponite from recycled water. J. Min. Sci. 2014, 50, 595-600. [CrossRef]

30. Chanturiya, V.; Minenko, V.; Makarov, D.; Suvorova, O.; Selivanova, E. Advanced techniques of saponite recovery from diamond processing plant water and areas of saponite application. Minerals 2018, 8, 549. [CrossRef] 
31. Minenko, V.; Denisova, J.; Samusev, A.; Makarov, D. Non-ferrous metal sorbents based on waste and side products of mineral beneficiation plants. J. Pol. Miner. Eng. Soc. 2019, 99-104. [CrossRef]

32. Pshinko, G.N.; Kobets, S.A.; Bogolepov, A.A.; Goncharuk, V.V. Treatment of waters containing uranium with saponite clay. J. Water Chem. Technol. 2010, 32, 10-16. [CrossRef]

33. Yanovska, E.; Nikolaeva, O.; Kondratenko, O.; Vretik, L. Sorption properties of saponite clay, in situ modified by poly(4-vinylpyridine-co-styrene), towards $\mathrm{Cu}(\mathrm{II}), \mathrm{Cd}(\mathrm{II}), \mathrm{Pb}(\mathrm{II}), \mathrm{Mn}(\mathrm{II})$ and $\mathrm{Fe}(\mathrm{III})$ ions. Fr. Ukr. J. Chem. 2019, 7, 145-152. [CrossRef]

34. Alemu, A.; Lemma, B.; Gabbiye, N. Adsorption of chromium(III) from aqueous solution using vesicular basalt rock. Cogent Environ. Sci. 2019, 5. [CrossRef]

35. Pandová, I.; Rimár, M.; Panda, A.; Valíček, J.; Kušnerová, M.; Harničárová, M. A study of using natural sorbent to reduce iron cations from aqueous solutions. IJERPH 2020, 17, 3686. [CrossRef] [PubMed]

36. Lagergren, S. Zur theorie der sogenannten adsorption gelöster stoffe: Lagergren, S., (Bihang, A.K. Svenske Vet. Ak. Handl. 24, II. Nr. 4, S. 49; 1899; Z. physik. Ch. 32, 174-175; 1900.). Zeitschr. F. Chem. Und. Ind. Der. Kolloide. 1907, 2, 15. [CrossRef]

37. Ho, Y.-S. Second-order kinetic model for the sorption of cadmium onto tree fern: A comparison of linear and non-linear methods. Water Res. 2006, 40, 119-125. [CrossRef]

38. Elovich, S.Y.; Larinov, O.G. Theory of adsorption from solutions of non electrolytes on solid (I) Equation adsorption from solutions and the analysis of its simplest form, (II) Verification of the equation of adsorption isotherm from solutions. Izv. Akad. Nauk. SSSR Otd. Khim. Nauk 1962, 2, 209-216.

39. Tran, H.N.; You, S.-J.; Hosseini-Bandegharaei, A.; Chao, H.-P. Mistakes and inconsistencies regarding adsorption of contaminants from aqueous solutions: A critical review. Water Res. 2017, 120, 88-116. [CrossRef]

40. Boyd, G.E.; Adamson, A.W.; Myers, L.S. The exchange adsorption of ions from aqueous solutions by organic zeolites. II. Kinetics ${ }^{1}$. J. Am. Chem. Soc. 1947, 69, 2836-2848. [CrossRef]

41. Weber Walter, J.; Morris, J. Carrell Kinetics of adsorption on carbon from solution. J. Sanit. Eng. Div. 1963, $89,31-60$.

42. Habte, L.; Shiferaw, N.; Khan, M.D.; Thriveni, T.; Ahn, J.W. Sorption of $\mathrm{Cd}^{2+}$ and $\mathrm{Pb}^{2+}$ on aragonite synthesized from eggshell. Sustainability 2020, 12, 1174. [CrossRef]

43. Abatal, M.; Córdova Quiroz, A.V.; Olguín, M.T.; Vázquez-Olmos, A.R.; Vargas, J.; Anguebes-Franseschi, F.; Giácoman-Vallejos, G. Sorption of $\mathrm{Pb}(\mathrm{II})$ from aqueous solutions by acid-modified clinoptilolite-rich tuffs with different Si/Al ratios. Appl. Sci. 2019, 9, 2415. [CrossRef]

44. Zhang, X.; Guo, S.; Liu, J.; Zhang, Z.; Song, K.; Tan, C.; Li, H. A study on the removal of Copper (II) from aqueous solution using lime sand bricks. Appl. Sci. 2019, 9, 670. [CrossRef]

45. Xu, X.; Lin, L.; Papelis, C.; Xu, P. Sorption of arsenic from desalination concentrate onto drinking water treatment solids: Operating conditions and kinetics. Water 2018, 10, 96. [CrossRef]

46. Fronczyk, J.; Mumford, K. The impact of temperature on the removal of inorganic contaminants typical of urban stormwater. Appl. Sci. 2019, 9, 1273. [CrossRef]

47. Lazarević, S.; Janković-Častvan, I.; Jovanović, D.; Milonjić, S.; Janaćković, D.; Petrović, R. Adsorption of Pb ${ }^{2+}$, $\mathrm{Cd}^{2+}$ and $\mathrm{Sr}^{2+}$ ions onto natural and acid-activated sepiolites. Appl. Clay Sci. 2007, 37, 47-57. [CrossRef]

48. Bujdák, J. Adsorption kinetics models in clay systems. The critical analysis of pseudo-second order mechanism. Appl. Clay Sci. 2020, 191, 105630. [CrossRef]

49. Wu, F.-C.; Tseng, R.-L.; Huang, S.-C.; Juang, R.-S. Characteristics of pseudo-second-order kinetic model for liquid-phase adsorption: A mini-review. Chem. Eng. J. 2009, 151, 1-9. [CrossRef]

50. Wu, F.-C.; Tseng, R.-L.; Juang, R.-S. Characteristics of Elovich equation used for the analysis of adsorption kinetics in dye-chitosan systems. Chem. Eng. J. 2009, 150, 366-373. [CrossRef]

51. Marcin, C.; Roman, P.; Joanna, W.; Piotr, K. Równowaga sorpcji w procesach usuwania jonów metali ciężkich ze środowiska wodnego. Weryfikacja statystyczna modeli matematycznych. Przemyst. Chemiczny. 2008, 87, 436-438.

52. Wang, A.; Wang, W. Introduction. In Nanomaterials from Clay Minerals; Elsevier: Amsterdam, The Netherlands, 2019; pp. 1-20, ISBN 978-0-12-814533-3.

53. Mudzielwana, R.; Gitari, M.W.; Msagati, T.A.M. Characterisation of smectite-rich clay soil: Implication for groundwater defluoridation. S. Afr. J. Sci. 2016, 112. [CrossRef] 
54. Drzymała, J.; Swatek, A. Mineral Processing: Foundations of Theory and Practice of Minerallurgy; University of Technology: Wroclaw, Poland, 2007; ISBN 978-83-7493-362-9.

55. Strawn, D.; Bohn, H.L.; O'Connor, G.A. Soil Chemistry, 5th ed.; John Wiley \& Sons: Hoboken, NJ, USA, 2020; ISBN 978-1-119-51518-0.

56. Arpa, C.; Say, R.; Satiroglu, N.; Bektas, S.; Yurum, Y.; Gnec, O. Heavy metal removal from aquatic systems by Northern Anatolian smectites. Turk. J. Chem. 2000, 24, 209-215.

57. Yavuz, Ö.; Altunkaynak, Y.; Güzel, F. Removal of copper, nickel, cobalt and manganese from aqueous solution by kaolinite. Water Res. 2003, 37, 948-952. [CrossRef]

58. Anthony, J.W.; Bideaux, R.A.; Bladh, K.W.; Nichols, M.C. (Eds.) Handbook of Mineralogy; Mineralogical Society of America: Chantilly, VA, USA, 2015.

59. Moussout, H.; Ahlafi, H.; Aazza, M.; Maghat, H. Critical of linear and nonlinear equations of pseudo-first order and pseudo-second order kinetic models. Karbala Int. J. Mod. Sci. 2018, 4, 244-254. [CrossRef]

60. Ho, Y.S.; McKay, G. Pseudo-second order model for sorption processes. Process Biochem. 1999, 34, 451-465. [CrossRef]

61. Taffarel, S.R.; Rubio, J. On the removal of $\mathrm{Mn}^{2+}$ ions by adsorption onto natural and activated Chilean zeolites. Miner. Eng. 2009, 22, 336-343. [CrossRef]

62. Khan, T.A.; Chaudhry, S.A.; Ali, I. Equilibrium uptake, isotherm and kinetic studies of Cd(II) adsorption onto iron oxide activated red mud from aqueous solution. J. Mol. Liq. 2015, 202, 165-175. [CrossRef]

63. Gupta, S.S.; Bhattacharyya, K.G. Adsorption of Ni(II) on clays. J. Colloid Interface Sci. 2006, 295, 21-32. [CrossRef]

Publisher's Note: MDPI stays neutral with regard to jurisdictional claims in published maps and institutional affiliations. 